\title{
MTHFR Gene
}

National Cancer Institute

\section{Source}

National Cancer Institute. MTHFR Gene. NCI Thesaurus. Code C18500.

This gene is involved in folate metabolism and methionine biosynthesis. 